\title{
Food Terrorism
}

\author{
Matthew N. O. Sadiku1, Sarhan M. Musa1, Tolulope J. Ashaolu²
}

\author{
${ }^{1}$ Roy G. Perry College of Engineering, Prairie View A\&M University, Prairie View, Texas, United States \\ ${ }^{2}$ College of Food Science Southwest University, Tiansheng Road Beibei, Chongqing, China
}

\begin{abstract}
How to cite this paper: Matthew N. O. Sadiku | Sarhan M. Musa | Tolulope J. Ashaolu "Food Terrorism" Published in International Journal of Trend in Scientific Research and Development (ijtsrd), ISSN: 24566470, Volume-3 | Issue-4, June 2019, pp.134-135, URL: https://www.ijtsrd. com/papers/ijtsrd2 3642.pdf

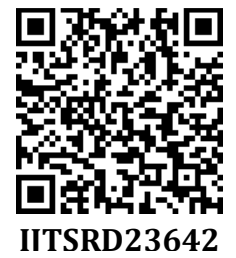

Copyright (c) 2019 by author(s) and International Journal of Trend in Scientific Research and Development Journal. This is an Open Access article distributed under the terms of the Creative Commons

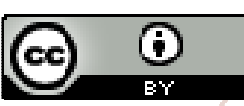
Attribution License (CC BY 4.0) (http://creativecommons.org/licenses/ by $/ 4.0$ )

An act of terrorism directed at the food and water supply could be devastating. Food terrorism will damage the main economy, especially the agriculture and tourism industries.

Food terrorist is group of individuals who are intentionally doing something to the food to either cause illness or death on a large scale. They are often politically, socially, or religiously oriented. Food terrorism may also involve food and water contamination with biological, chemical, and physical materials for the purpose of causing injury or deat and/or disrupting social, economic or political stability. Intentional food and water contamination has been with us for a very long time. Acts of terrorism using bombs and explosive devices occur around the world. Bombings have been the most commonly used terrorist method of attack. Although food terrorism issues are global, its prevention must start locally. So far there has not been any documented terrorist attack on US agriculture. A terrorist attack on the food supply is possible. An example is Salmonella contamination of salad bars in Oregon in the 1980s.

\section{CAUSES OF FOOD TERRORISM}

The food supply chain is an attractive, easy target for terrorist attacks. Agriculture/ food industry is one of the seventeen national critical sectors of US economy. Deliberate contamination of food supply may easier to control than attacks through air or water. This may also have enormous economic and social implications.

Terrorists can utilize the food supply to create fear, cause public harm, and damage food company brand. Food terrorism may be caused by the following reasons [1]. First, food price fluctuations are significant predictors of terrorism within a nation. Second, rapid food price increases terrorist attacks. Third, both country level of economic development and country political regime type amplify or negate the effects of food price volatility on terrorist activity. Government's attempt to eliminate subsidies of basic food items have been observed to increase public protests, violent strikes, or riots. Other reasons include globalization of the food supply, which contributes new risks.

\section{PREVENTING FOOD TERRORISM}

Prevention and early detection of a terrorism attack is the best way to address the problem. Food defense is basically the process of protecting the food supply from deliberate contamination as a result of terrorist activity. It should be an integral part of food supply chain since it is far cheaper to prevent an incident from occurring than dealing with the aftermath. Food defense methods seek to prevent deliberate attacks on the food supply and also food fraud, food crime, food adulteration, food contamination, and food tampering [2].

Shortly after the devastating attacks of September 11, 2001, President George W. Bush declared that "our war on terror begins with al-Qaida, but it does not end there. It will not end until every terrorist group of global reach has been found, stopped, and defeated" [3]. After 9/11, the US increased its efforts for food protection by making coordination of food defense the responsibility of the Department of Homeland Security (DHS). The Food and Drug Administration (FDA) 
has authority to act to protect the safety of the nation's food supply. The agency will protect the general public from food terrorism by preparing the agency to take appropriate action in the event of a crisis. FDA has disseminated messages intended to increase the awareness of government agencies, industry representatives, and consumers regarding food terrorism and make good decisions in the event of a food terrorism threat.

The government does not have a single approach to preventing food terrorism. Instead, the agencies work with food producers to work and device schemes to prevent terrorists from infiltrating the food supply [4]. The government agencies (USDA, FDA, DHS, FBI) alone are not solely responsible to prevent food terrorism. Food processors can play a vital role to insure that terrorists do not use food as a weapon. The food industry, regulatory authorities, and consumers must focus on the need for effective food defense systems [5]. Food regulatory officials should enforce preventive measures during regular inspections of food establishments and food importers. Places where food is stored should be secured, and steps taken to prevent adulteration.

\section{REFERENCES}

[1]. J. A. Piazza, "The cost of living and terror: Does consumer price volatility fuel terrorism?" Southern Economic Journal, vol. 79, no. 4, 2013, pp. 812-831.

[2]. R. K. Davidson, "From food defence to food supply chain integrity," British Food Journal, vol. 119, no. 1, 2017, pp. 52-66.

[3]. C. Tilly, "Terror, terrorism, terrorists," Sociological Theory, vol. 22:=, no.1, March 2004.

[4]. L. Rothman, "The link between food security and terrorism is surprisingly complicated, report shows," October 2018, https://munchies.vice.com/en_us/article/bj4qkw/thelink-between-food-security-and-terrorism-issurprisingly-complicated-report-shows

[5]. E. Yoon and C. W. Shankli, "Implementation of food bio security management plan against food terrorism in on-site foodservice operations," Journal of Hospitality \& Tourism Research, vol. 31, no. 2, May 2007, pp. 224240.

[6]. N. J. Neher, "The need for a coordinated response to food terrorism: The Wisconsin experience," Annals New York Academy of Sciences, vol. 894, 1999,. pp. 181-183.
The food industry has the primary responsibility for ensuring that retail food products are safe for consumption. Threats must be taken seriously and acted upon quickly. A structure must be in place to coordinate and handle terrorist. If criminal action is suspected, there must be adequate resources and expertise [6].

\section{CONCLUSION}

Food terrorism, possibly caused by accidental or deliberate food contamination, is a real threat to every country that loves freedom. Terrorist elements exist and are active in every nation. Food terrorism is increasingly aided by the globalization of the food supply. It can have far reaching impact on individuals and society and may cause social, economic, and political disruption. Therefore, responsible governments and organizations should not ignore the possibility that terrorists may target the food supply.

Food terrorism is an under-researched phenomenon and there is limited information on the topic. More information about food terrorism can be obtained from the books in [7-8] and also from the journal: British Food Journal

[7]. World Health Organization, "Terrorist Threats to Food: Guidance for Establishing and Strengthening Prevention and Response Systems," 2003, https://apps.who.int/iris/handle/10665/42619

[8]. H. W. Richardson, P. Gordon, and J. E. Moore II, (eds.), The Economic Costs and Consequencies of Terrorism. Cheltenham, UK: Edward Elgar, 2007.

\section{AUTHORS PROFILE}

Matthew N.O. Sadiku is a professor in the Department of Electrical and Computer Engineering at Prairie View A\&M University, Prairie View, Texas. He is the author of several books and papers. His areas of research interests include computational electromagnetic and computer networks. He is a fellow of IEEE.

Tolulope J. Ashaolu is a postdoctoral research fellow at Southwest University, Chongqing, China. He is the author of several papers and a book. His research interests include functional foods and food microbiology.

Sarhan M. Musa is a professor in the Department of Engineering Technology at Prairie View A\&M University, Texas. He has been the director of Prairie View Networking Academy, Texas, since 2004. He is an LTD Sprint and Boeing Welliver Fellow. 